\author{
Chirurgia (2020) 115: 385-393 \\ No. 3, May - June \\ Copyright@ Celsius \\ http://dx.doi.org/10.21614/chirurgia.115.3.385
}

\title{
Totally Laparoscopic Pancreaticoduodenectomy: Technical Notes
}

\author{
Michele Mazzola, Lorenzo Morini, Jacopo Crippa*, Marianna Maspero, Andrea Zironda, Alessandro Giani, \\ Paolo De Martini, Giovanni Ferrari
}

ASST Grande Ospedale Metropolitano Niguarda, Division of Minimally-invasive Surgical Oncology, Milan, Italy

Corresponding author:

*Jacopo Crippa, MD

Division of Oncologic and

Mini-invasive General Surgery

ASST Grande Ospedale

Metropolitano Niguarda

Piazza dell'Ospedale Maggiore

3 20162, Milan, Italy

E-mail: jacopocrippamd@gmail.com

Received: 10.05 .2020

Accepted: 15.06 .2020

\section{Rezumat}

Duodenopancreatectomia laparoscopică totală: note tehnice

Introducere: Duodenopancreatectomia laparoscopică este încă rar adoptată datorită complexității sale inerente. Acest articol prezintă experiența noastră de duodenopancreatectomie laparoscopică axată pe note tehnice.

Descrierea tehnică:Se foloseşte o tehnică cu 5 trocare. Vizibilitatea este asigurată de un telescop optic $30^{\circ} \mathrm{cu}$ tehnologie $4 \mathrm{~K}$ pentru rezecție şi $3 \mathrm{D}$ pentru faza reconstructivă. Flexura colică dreaptă este mobilizată şi se efectuează manevra Kocher extinsă care expune vena cava inferioară şi vena renală stângă. Antrul gastric este rezecat cu un capsator mecanic. Artera hepatică comună este identificată în spatele marginii pancreatice superioare; limfadenectomia stațiilor $7,8,9,12$ a şi b este efectuată, până când artera gastroduodenală este curățată de țesutul limfatic; o pensă bulldog este folosită pentru a întrerupe fluxul arterial prin artera gastroduodenală, pentru a exclude vascularizarea arterelor aberante ale ficatului din artera mezenterică superioară. Ductul hepatic comun este sectionat chiar deasupra canalului chistic. Pancreasul este secționat prin electrochirurgie monopolară, împărțind canalul pancreatic principal la 2-3 mm distal de sectiunea transversală prin parenchim cu foarfece reci, pentru a lăsa un ciot care va facilita anastomoza ducto-mucoasă, apoi se secționează prima buclă jejunală. Se realizează o disecție completă a mezopancreasului, de la coadă la cap. Inainte de a efectua anastomoza pancreatico-jejunală, se evaluează un scor de risc al fistulei bazat pe textura parenchimului pancreatic, tipul tumorii, diametrul ductului Wirsung, pierderea de sânge intraoperator. 
Anastomoza pancreatico-jejunală se realizează folosind fire din prolen şi PDS. Hepaticojejunostomia termino-laterală se efectuează la aproximativ $10 \mathrm{~cm}$ de pancreatico-jejunostomie. Gastrojejunostomia laterală se realizează cu ajutorul unui capsator liniar de $60 \mathrm{~mm}$.

Concluzie:Duodenopancreatectomia laparoscopică este o procedură dificilă afectată de rate mari de morbiditate. Standardizarea tehnicii ar putea duce la reducerea acestor rate şi la favorizarea adoptării acesteia.

Cuvinte cheie: duodenopancreatectomie laparoscopică totală, duodenopancreatectomie laparoscopică, intervenție chirurgicală minim invazivă, chirurgie pancreatică, cancer pancreatic

\section{Abstract}

Introduction: Laparoscopic pancreaticoduodendectomy is still rarely adopted due to its inherent complexity. We hereby present our experience of laparoscopic pancreaticoduodenectomy focused on technical notes.

Technical description: A 5 trocars technique is used. Vision is provided by a $30^{\circ}$ scope with $4 \mathrm{~K}$ technology for the demolitive phase and $3 \mathrm{D}$ for the reconstructive phase. The right colic flexure is mobilized and an extensive Kocher maneuver is carried out exposing the inferior vena cava and left renal vein. The gastric antrum is resected with a mechanical stapler. The common hepatic artery is identified behind the superior pancreatic margin; lymphadenectomy of stations 7, 8, 9, 12 a and b is performed, until the gastroduodenal artery is cleared from the lymphatic tissue; a bull-dog clamp is placed to interrupt the arterial flow through the gastroduodenal artery, in order to exclude aberrant vascularization of the liver from the SMA. The common hepatic duct is transected just above the cystic duct. The pancreas is sectioned with monopolar energy, dividing the main pancreatic duct 2-3 mm distal to the parenchymal transection line with cold scissors, as to leave a stump that will facilitate the duct-to-mucosa anastomosis then the first jejunal loop is sectioned. A complete dissection of the mesopancreas is performed, moving from a caudal to cephalad fashion. Prior to perform the pancreatico-jejunal anastomosis, a fistula risk score based on pancreatic parenchymal texture, tumor type, Wirsung diameter, intraoperative blood loss is assessed. The pancreatico-jejunal anastomosis is carried out using prolene and pds sutures. The end-to-side hepaticojejunostomy is performed about $10 \mathrm{~cm}$ distant from the pancreaticojejunostomy. The sideto-side gastrojejunostomy is performed using a $60 \mathrm{~mm}$ linear stapler.

Conclusion: Laparoscopic pancreaticoduodenectomy is a demanding procedure affected by high morbidity rates. The standardization of the technique could lead the way to reduce such rates and favor its adoption.

Key words: total laparoscopic pancreaticoduodenectomy, laparoscopic pancreaticoduodenectomy, advanced minimally invasive surgery, pancreatic surgery, pancreatic cancer

\section{Introduction}

Initial experiences of minimally invasive surgery applied to pancreatic diseases were limited to the diagnostic and stadiative phases or palliative procedures $(1,2)$. During the last decades, the technological and surgical progress has resulted into a wider spectrum of minimally invasive operations in the field of pancreatic surgery, for the treatment of both benign and malignant neoplasms (3). In this scenario, laparoscopic distal 
pancreatectomy has already achieved acceptance worldwide (4). This operation does not require any anastomosis, and it is considered feasible and safe (3). On the other hand, laparoscopic pancreaticoduodenectomy (LPD) is still questioned to be as safe and reproducible, due to its technical complexity and long operative time $(3,5)$. Although the first LPD was performed more than 20 years ago (6), the adoption rate has been very low (7), especially when compared to other fields of surgical oncology for which laparoscopy is routinely applied (3). The technical complexity, especially related to the dissection close to the vascular structures and to the difficulty of creating multiple anastomoses, represents the main reason that limits the adoption of LPD (8).

Recent retrospective series have reported multiple advantages in short term outcomes for LPD compared to open PD (9-11). Considering its potential benefits, efforts should be made to improve the diffusion and standardization of LPD technique worldwide.

We hereby present our experience of LPD with regards to the operatory phases and technical aspects.

\section{Surgical Technique}

\section{Patient's Preparation and Positioning}

The patient receives low molecular weight heparin starting the evening before the surgery. Cefazolin $2 \mathrm{~g}$ is administered as antibiotic prophylaxis 15 minutes prior the skin incision.

Intermittent pneumatic compression devices are positioned on the lower extremities to prevent thromboembolic events; feet and right shoulder supports are positioned, to allow optimal bed mobilization.

The patient is placed supine, with legs apart, with the first surgeon positioned between the legs and one assistant on each side of the patient's abdomen.

\section{Demolitive Phase}

The first trocar is placed in supra-umbilical position; 2 other trocars are positioned on each side of the umbilicus (Fig. 1). A $30^{\circ}$ scope is used with $4 \mathrm{~K}$ technology. The pneumoperitoneum is insufflated at $12 \mathrm{mmHg}$. The bed is tilted in a $30^{\circ}$ reverse Trendelenburg position. A percutaneous traction suture is placed on the round ligament to lift the liver in an upward position.

The abdominal cavity is explored to exclude the presence of macroscopic metastatic disease on the liver surface and the peritoneum. The gastrocolic ligament is then opened and dissected using a radiofrequency energy device, preserving the left gastroepiploic vessels. The right colic flexure is mobilized and an extensive Kocher maneuver is carried out exposing the inferior vena cava (IVC) and

Figure 1. Trocars' position
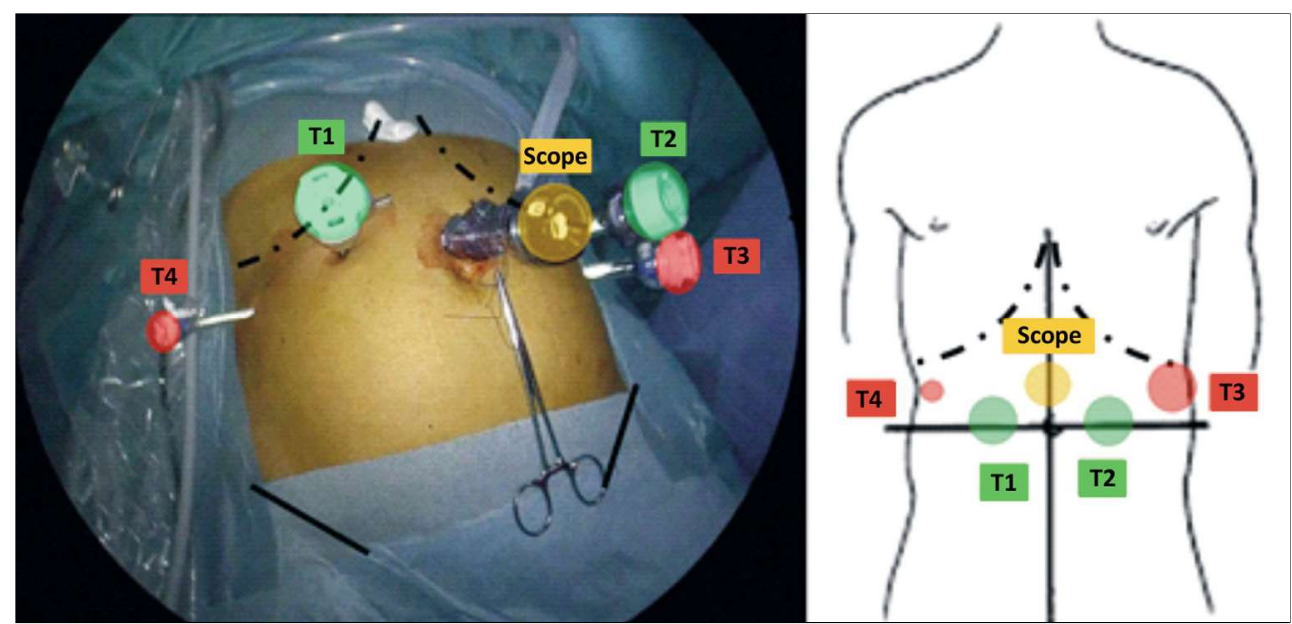


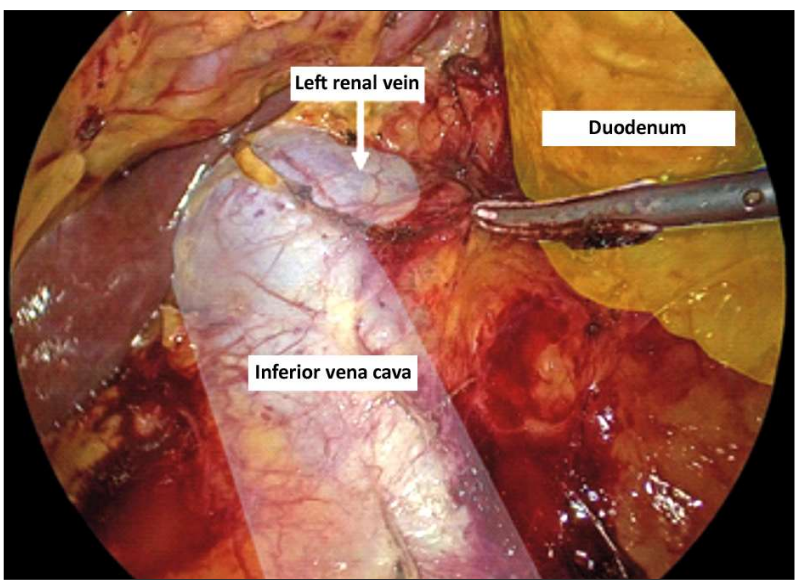

Figure 2. Kocher maneuver

left renal vein (LRV) (Fig. 2); the origin of the superior mesenteric artery (SMA) is identified in order to evaluate resectability. The lastthird of the duodenum is separated from the transverse mesocolon with identification and partial dissection of the superior mesenteric vein (SMV) in order to rule out any neoplastic involvement. The lymph nodes of the superior mesenteric vein are excised and the right gastroepiploic vessels are sealed at trunk of Henle using clips (Fig. 3). The gastric antrum is resected (Whipple's procedure) with a 60 $\mathrm{mm}$ stapler with purple cartridge (SigniaTM $\AA$, Ultra Powered stapling System, Covidien).

The common hepatic artery is identified behind the superior pancreatic margin; lymphadenectomy of stations $7,8,9,12$ a and $\mathrm{b}$ is performed, until the gastroduodenal artery (GDA) is cleared from the lymphatic tissue; a bull-dog clamp is placed to interrupt the arterial flow through the GDA (Fig. I), in order to exclude aberrant vascularization of the liver from the SMA. The gallbladder is dissected from the hepatic bed, sectioning the cystic artery at its origin; a careful dissection of the hepatic pedicle is performed in a caudal to cephalad fashion, and the common hepatic duct (CHD) is transected just above the cystic duct (Fig. 5); a frozen section of the resection margin is performed to exclude neoplastic involvement and a bile sample is obtained for microbiological purpose. The distal stump of the CHD is then closed with a running suture

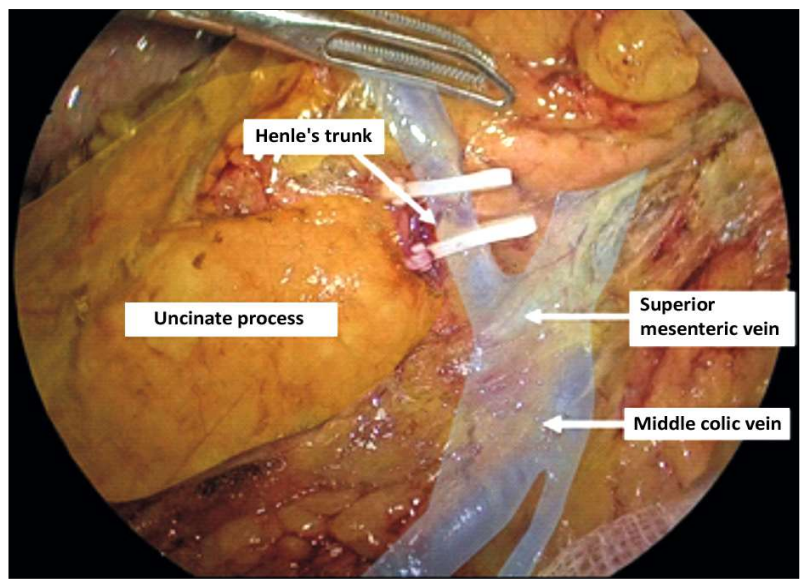

Figure 3. Henle's Trunk

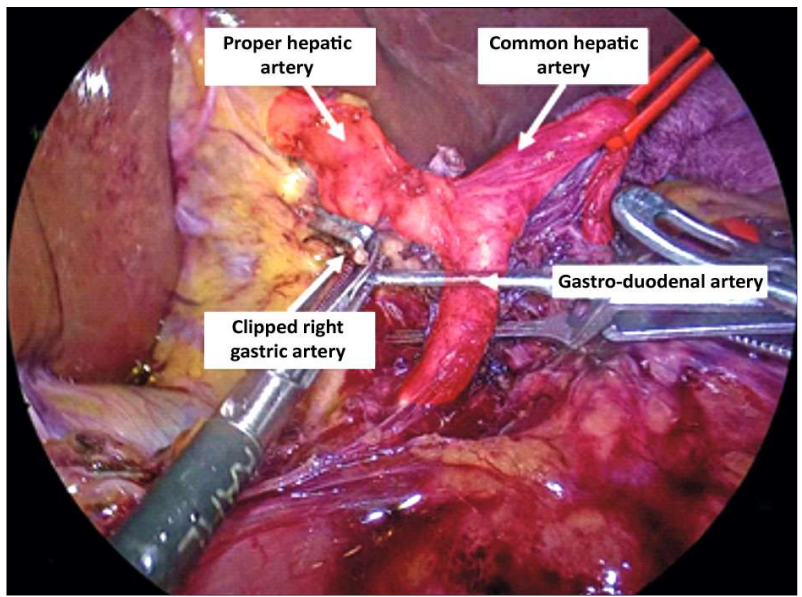

Figure 4. Gastro-duodenal artery

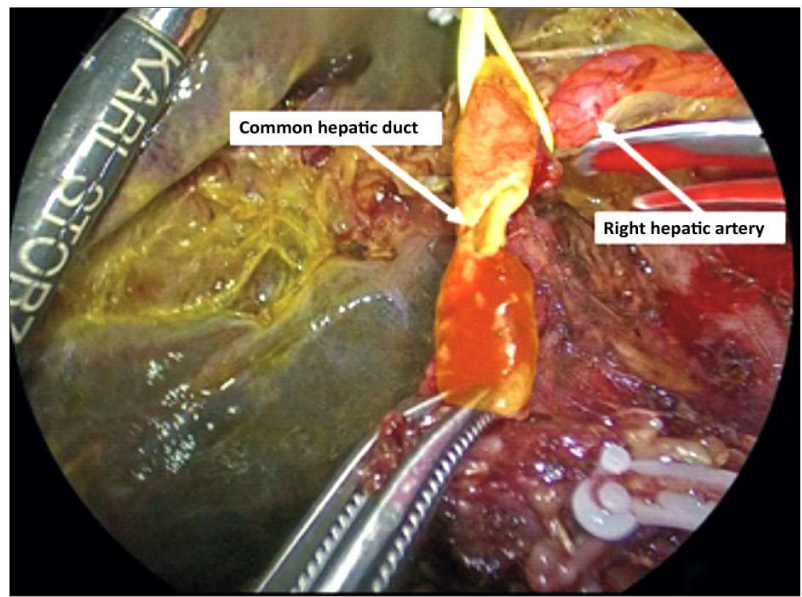

Figure 5. Biliary duct sectioned 
or a clip. After assessing the correct liver and bowel perfusion, the GDA is sealed with clips or vascular stapler depending on the dimension.

The portal vein is cleared by the surrounding lymphovascular tissue in a cephalad to caudal fashion until the anterior-superior-pancreatico-duodenal vein (ASPDV) (Fig. 6). The retropancreatic tunnel is completed and the pancreatic neck is surrounded with a cloth loop. The pancreas is sectioned with monopolar energy, dividing the main pancreatic duct $2-3 \mathrm{~mm}$ distal to the parenchymal transection line with cold scissors, as to leave a stump that will facilitate the duct-to-mucosa anastomosis (Fig. 7). An intraoperative frozen section of the pancreatic margin is obtained to rule out neoplastic involvement.

The transverse colon is brought upwards to expose the Treitz ligament, which is dissected up to the lower edge of the pancreas; the first jejunal loop is sectioned approximately $7 \mathrm{~cm}$ below the Treitz with $60 \mathrm{~mm}$ tristaple Endo Gia (SigniaTM ${ }^{\circledR}$, Ultra Powered stapling System, Covidien).

The second part of the duodenum and the fist jejunal loop are lifted up and pushed toward the left by the assistants' grasp showing the resection plane along the SMA (Fig. 8); a complete dissection of the mesopancreas is performed, moving from a caudal to cephalad fashion parallel to the SMA; the whole lymphovascular tissue between the uncinate process and the antero-right lateral aspect of the SMA is dissected. The vessels in the mesopancreas are sealed using $5 \mathrm{~mm}$ pneumatic clips (Challenger ${ }^{\circledR}$ Ti-P, B. Braun); if possible, the inferior pancreatico-duodenal artery (IPDA) should be always sealed with clips. The dissection is completed removing all the tissue between the celiac trunk and the SMA; at the end, lymphadenectomy of the station $12 \mathrm{~b}$ is completed.

Surgical specimen is positioned in an endobag and extracted through a Pfannenstiel mini-laparotomy $(4-5 \mathrm{~cm})$.

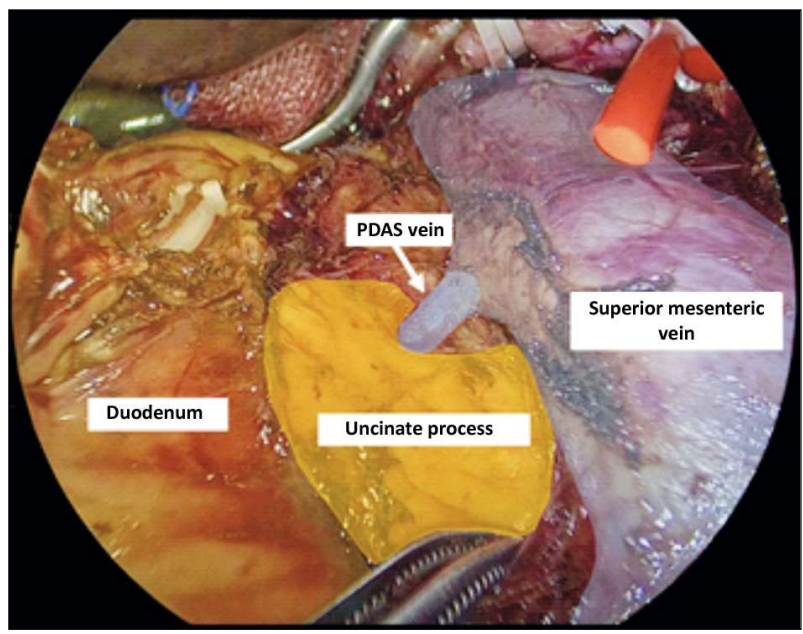

Figure 6. Pancreatic-duodenal anterior superior vein

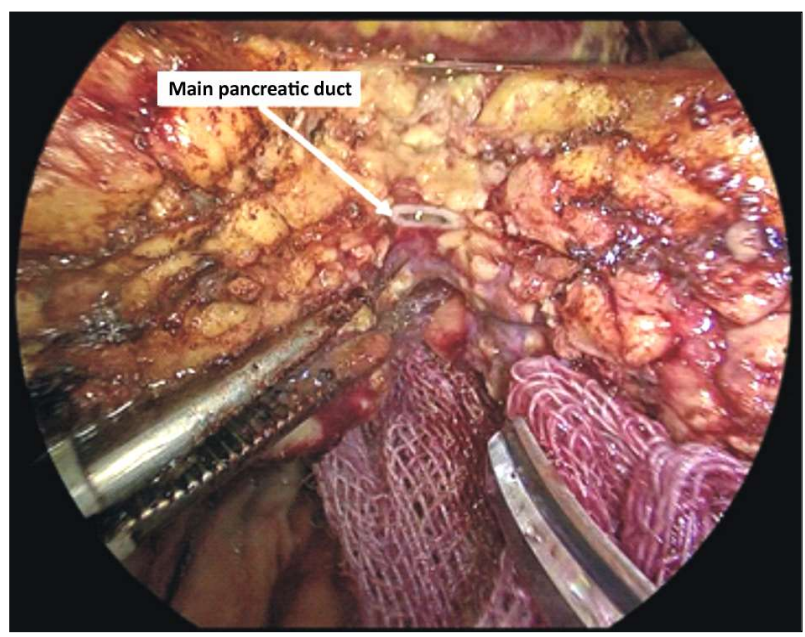

Figure 7. Main pancreatic duct

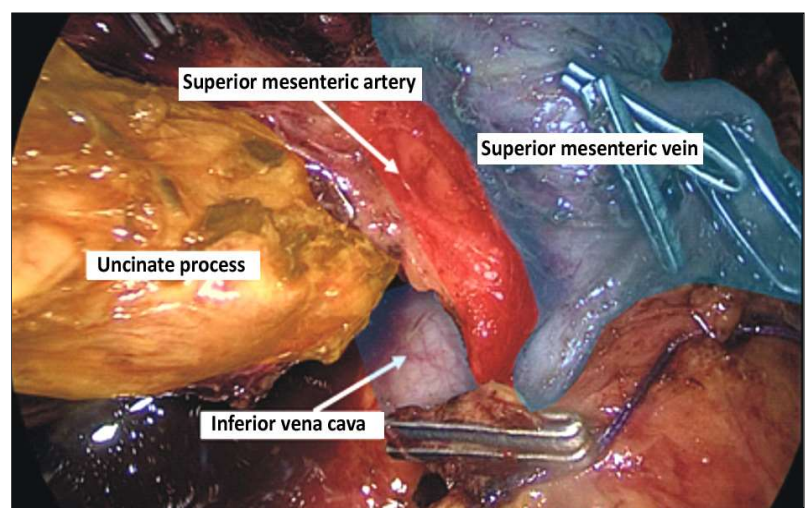

Figure 8. Identification of superior mesenteric artery 


\section{Reconstructive Phase}

The $4 \mathrm{~K}$ scope is replaced with a $30^{\circ} 3 \mathrm{D}$ one for the reconstructive phase, performed according to Child; the jejunal loop is transposed supramesocolic through behind the mesenteric root.

Prior to perform the pancreatico-jejunal anastomosis, a fistula risk score based on pancreatic parenchymal texture, tumor type, Wirsung diameter, intraoperative blood loss is assessed (12).

The pancreatic remnant is mobilized for about $3-4 \mathrm{~cm}$ and a 2-0 absorbable polyfilament stitch (Vicryl ${ }^{\circledR}$, Ethicon Endosurgery Inc, Cincinnati, $\mathrm{OH}$ ) is placed on both side of the pancreas to help with traction. Six interrupted absorbable 5-0 monofilament sutures (PDS $\AA$, Ethicon Endosurgery Inc, Cincinnati, $\mathrm{OH})$, with RB-1 needle, are placed in the

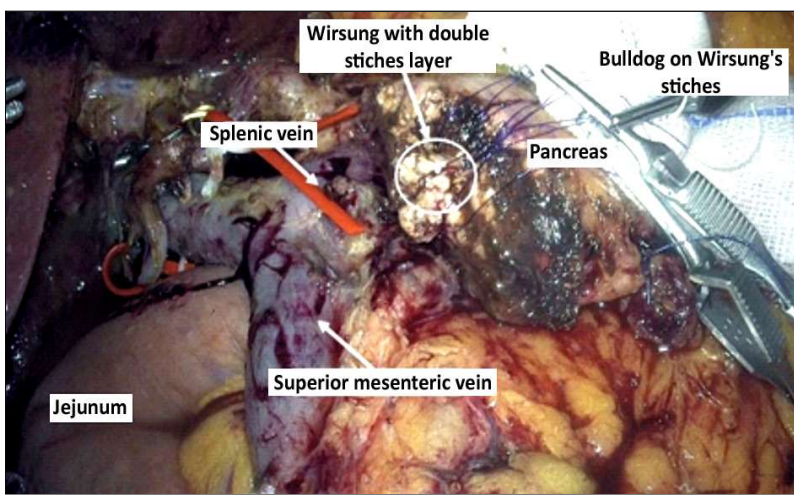

Figure 9. Stiches positioning on the Wirsung duct

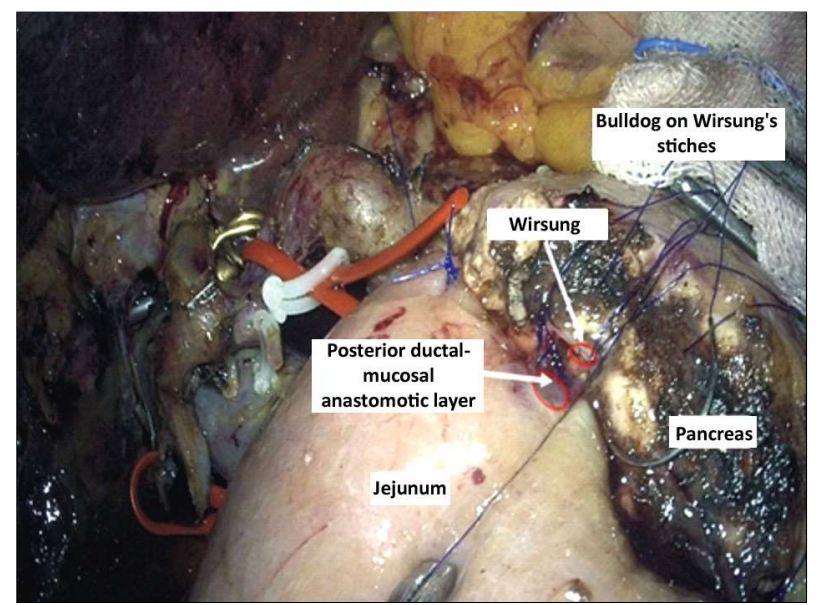

Figure 11. Duct-to-mucosal posterior layer
Wirsung (3 anterior and 3 posterior), independently from the diameter of the duct. Each suture is abandoned over the pancreatic remnant with the two extremities hold with a marked micro bull-dog (Fig. 9).

The posterior layer of the anastomosis in performed using interrupted non-absorbable 4-0 polypropylene (Prolene ${ }^{\circledR}$, Ethicon Endosurgery Inc, Cincinnati, $\mathrm{OH}$ ) with an SH needle, between the sero-muscolar jejunal layer and the pancreatic capsula, from cephalad to caudal (Fig. 10); then an enterotomy is performed on the anastomotic jejunal loop, using the monopolar crochet, corresponding to the site and the diameter of the Wirsung duct. The duct-to-mucosa anastomosis is then fashioned, using the interrupted sutures previously placed in the Wirsung duct (Fig. 11-12). Finally, the

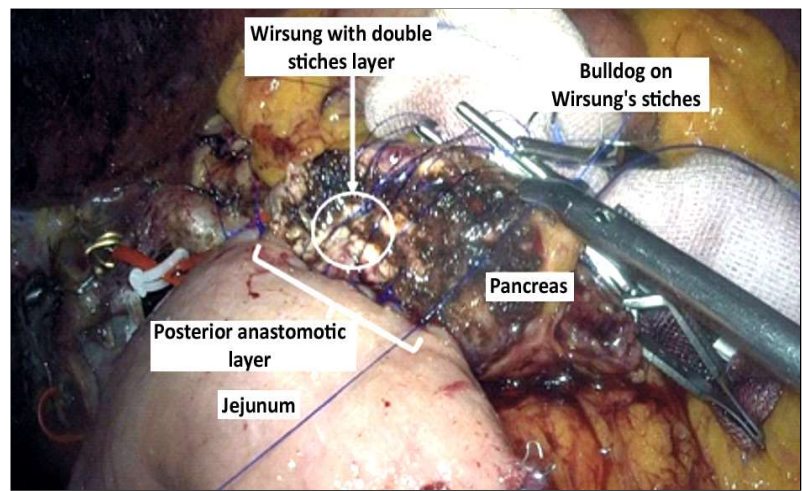

Figure 10. Posterior layer of pancreatico-jejunal anastomosis

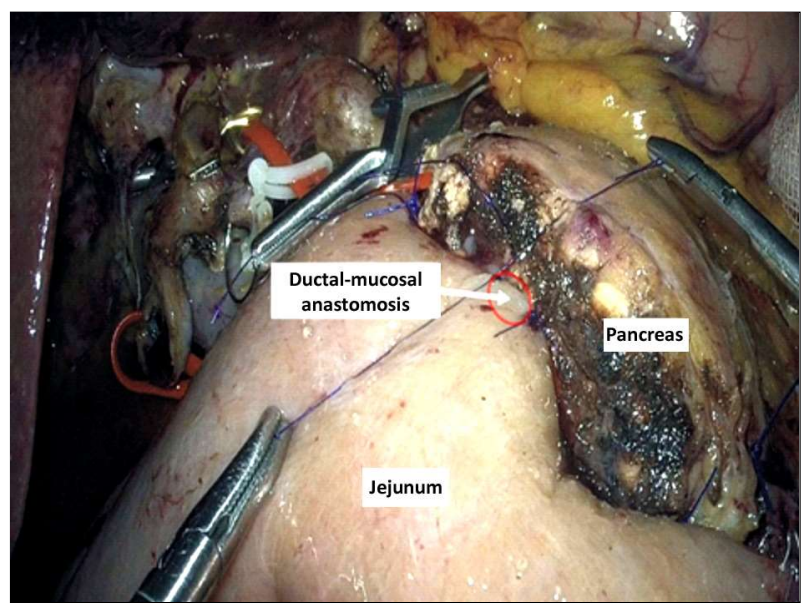

Figure 12. Duct-to-mucosal anterior layer 
anterior layer of the pancreato-jejunal anastomosis is sutured similarly to the posterior one (Fig. 13).

The end-to-side hepaticojejunostomy is performed about $10 \mathrm{~cm}$ distant from the pancreaticojejunostomy. Usually, two 5-0 monofilament running sutures $(\mathrm{PDS} \AA$, Ethicon Endosurgery Inc, Cincinnati, OH) with RB 1 needle are used; first, the posterior layer is sutured in a lateral-to-medial direction and then the anterior one in the opposite way (Fig. 14). The knot of each suture falls outside of the anastomosis and never inside (Fig. 15). When the bile duct has a small diameter, the anastomosis is performed using interrupted 5-0 monofilament sutures (PDS $\AA$, Ethicon Endosurgery Inc, Cincinnati, OH).

The side-to-side gastrojejunostomy is performed using a $60 \mathrm{~mm}$ linear stapler (SigniaTM ${ }^{\circledR}$, Ultra Powered stapling System, Covidien) with a purple cartridge and two 3-0 running suture (V-Loc $\AA$, Covidien, Inc, Mansfield, Massachusetts, USA) close the hole of the stapler insertion.

This anastomosis is carried out in an antecolic fashion, between the posterior wall of the stomach and the jejunal loop, along the greater curvature, following omental split.

Two closed suctioning drain (JacksonPratt $($ ) are finally placed: the right drain goes behind the hepaticojejunostomy and cranially to the pancreaticojejunostomy; the left one goes behind the gastrojejunostomy and beneath the pancreaticojejunostomy. The naso-gastric tube is removed at the end of the procedure.

\section{Discussion}

Due to its technical complexity, LPD is a demanding procedure with poor standardization and a long learning curve (12). A correct indication to LPD and a careful patient selection is of paramount importance and depends on the surgical team experience: at the beginning of the learning curve, small ampullary or distal biliary tract tumors and patients with low BMI could facilitate the surgery and result in a lower conversion and injury rate (13-14).

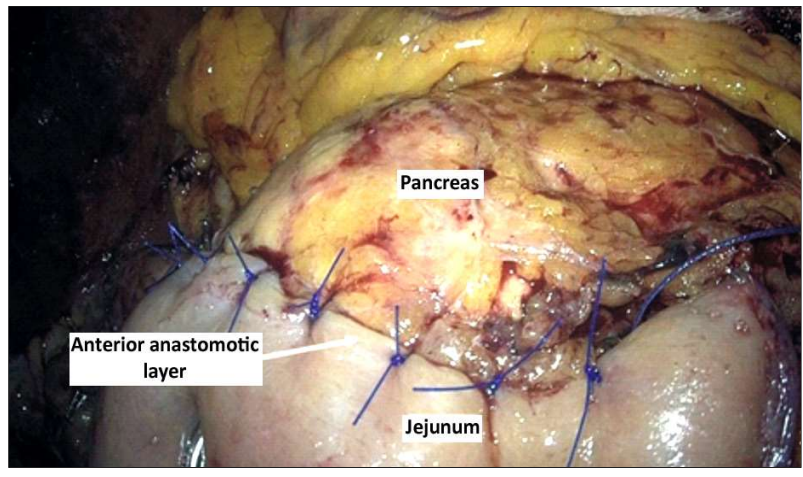

Figure 13. Anterior layer of pancreatico-jejunal anastomosis

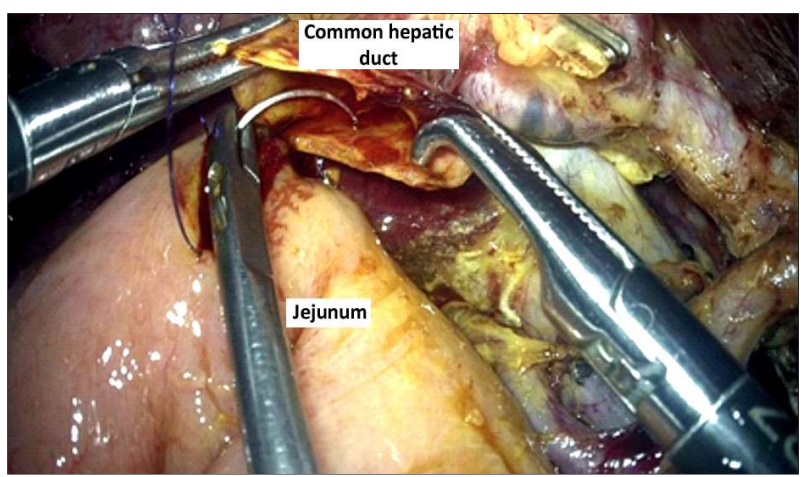

Figure 14. Biliary duct anastomosis

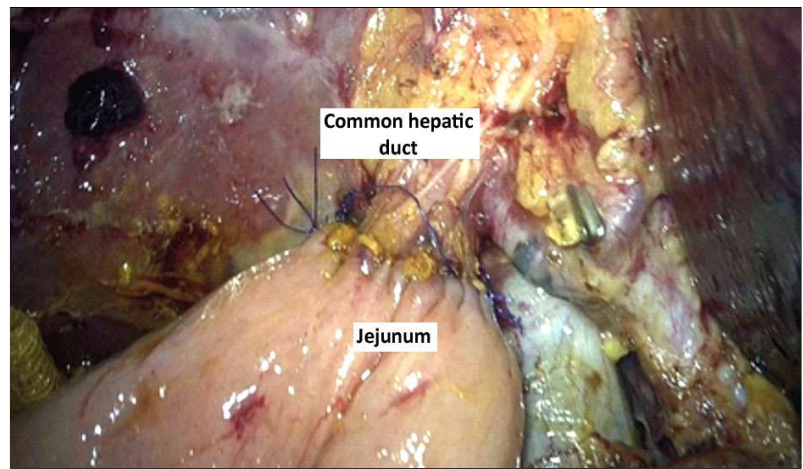

Figure 15. End of biliary duct anastomosis

Relative contraindication to LPD are related to the patients' fitness status (significant comorbidities $(1,2,15,16)$, previous upper-mesocolic abdominal surgeries $(1,16,17,18))$ or to the primary disease (large tumours $(1,19)$, previous chronic pancreatitis, neoadjuvant radiotherapy $(19,20)$, and neoplastic vascular involvement $(13,15))$.

In our institution, we offer a minimally 
invasive option to all patients that will receive PD, except for the cases with vascular infiltration, previous neoadjuvant therapy or anesthesiological contraindications to laparoscopy.

To perform LPD we use 5 trocars, different from other authors that described a $6(9,21)$, or, more rarely, $7(18,22)$ trocars technique. This setting allows to perform all the steps of the intervention without changing the position of the operators with a good visualization of all the regions; the first operator is positioned between the patient's legs; the first assistant (on the patient's left) plays a dynamic role, helping in the introduction and extraction of gauzes and surgical specimens through a 12 $\mathrm{mm}$ trocar; the second assistant can retract the liver or do traction according to the phase of the intervention through a $5 \mathrm{~mm}$ trocar.

Pancreatic neck is sectioned using cold shear, to easily identify and avoid thermal injuries of the Wirsung duct that could lead to pancreatic stump pancreatitis, as hypothesized by some authors (23).

Our technique consists of a particular dissection of retroportal lamina using a modified "artery first approach"; this is obtained firstly by approaching the lamina "downward", with a clear visualization of the resection plane along the SMA and an easier and reproducible identification of the IPDA; once the IPDA is sectioned, the lamina is approached by "upperward", with the section of pancreatico-duodenal veins and completing the total mesopancreas excision (TMpE).

We always perform TMpE, as we deem it advantageous both in case of benign disease and malignancy: in the first case, it allows easier recognition of the correct dissection plane, reducing bleeding; in the second one, it reduces the incidence of $\mathrm{R}+$ resections improving the posterior margin clearance and the number of harvested lymphnodes, compared to standard pancreaticoduodenectomy (24).

The specimen is extracted by using an endobag through a suprapubic Pfannenstiel incision as it reduces the risk of incisional hernia and surgical site infection (25). This extraction site is reported in $15.7 \%$ of cases in the literature and is the second most common one after minilaparotomy at the umbilical port (42.2\%) (26-28). Other described extraction sites are subxiphoid (15\%) (16,29), sub-umbilical (8.9\%) (21) and right inferior quadrant (8.8\%) $(1,30)$ mini-laparotomies.

We perform the reconstructive phase using a 3D scope, taking advantage of the enhanced depth perception. We perform a pancreaticojejunal anastomosis, as most authors do (84\%); less common anastomoses are pancreaticogastrostomy (9,8\% of cases) and duct occlusion $(6,8 \%)(1,16,26,30)$. There is no strong evidence in favor of pancreatojejuno-stomy vs pancreatogastrostomy (32). At the beginning of our experience, we used to perform the anastomosis with two running sutures, but the drawback of this technique is that in case of a suture line dehiscence, it would involve half of the anastomosis. We now use a double layer of interrupted sutures, similarly to the majority of authors (respectively 90,6\% for double layer and $74,6 \%$ for interrupted sutures) $(14,21)$. We use poly-propylene and polydioxanone sutures because they have less variation after exposure to pancreatic juice, bile, and their mixture (33).

Many authors $(72,8 \%)$ place a stent in the pancreatic duct, either routinely or selectively, to reduce the risk of postoperative pancreatic fistula (POPF) (33). We never place stents in the Wirsung duct because of no evidence of minor risk of POPF (35) and higher risk of early stent occlusion, with consequent pancreatitis of the stump (23).

Consistently to most reported series, we perform an antecolic gastrojejunal anastomosis in order to improve gastric emptying; other authors perform a retromesenteric or retrocolic anastomosis $(1,27,28)$. In most reported cases, gastrojejunal (or duodenojejunal) anastomosis are hand sewn $(3,10,14,31)$; mechanical gastrojejunal anastomoses are reported in the minority of cases $(5,14,21)$.

LPD is a technically demanding operation with a steep learning curve; building a dedicated surgical team, the standardization of the technique and the development of advanced laparoscopic skills could be useful to 
favor its adoption and improve intra- and postoperative outcomes.

\section{Conflict of Interest}

The authors declare no conflicts of interests.

\section{References}

1. Corcione F, Pirozzi F, Cuccurullo D, Piccolboni D, Caracino V, Galante F, et al. Laparoscopic pancreaticoduodenectomy: Experience of 22 cases. Surg Endosc. 2013:27(6):2131-6.

2. Palanivelu $C$, Jani $K$, Senthilnathan $P$, Parthasarathi $R$, Rajapandian $S$, Madhankumar MV. Laparoscopic pancreaticoduodenectomy: technique and outcomes. J Am Coll Surg. 2007;205(2):222-30.

3. Ammori BJ, Ayiomamitis GD. Laparoscopic pancreaticoduodenectomy and distal pancreatectomy: A UK experience and a systematic review of the literature. Surg Endosc. 2011;25(7):2084-99.

4. Mabrut JY, Fernandez-Cruz L, Azagra JS, Bassi C, Delvaux G, Weerts J, et al. Laparoscopic pancreatic resection: results of a multicenter European study of 127 patients. Surgery. 2005; 137(6):597-605.

5. Dulucq JL, Wintringer P, Mahajna A. Laparoscopic pancreaticoduodenectomy for benign and malignant diseases. Surg Endosc. 2006; 20(7):1045-50.

6. Gagner M, Palermo M. Laparoscopic Whipple procedure: review of the literature. J Hepatobiliary Pancreat Surg. 2009;16(6):726-30.

7. Merkow J, Paniccia A, Edil BH. Laparoscopic pancreaticoduodenectomy: a descriptive and comparative review. Chin J Cancer Res. 2015;27(4):368-75.

8. Umemura A, Nitta H, Takahara T, Hasegawa Y, Sasaki A. Current status of laparoscopic pancreaticoduodenectomy and pancreatectomy. Asian J Surg. 2018;41(2):106-114. Epub 2016 Sep 27.

9. Asbun HJ, Stauffer JA. Laparoscopic vs open pancreaticoduodenectomy: overall outcomes and severity of complications using the accordion severity grading system. J Am Coll Surg. 2012; 215(6):810-9. Epub 2012 Sep 19.

10. Croome KP, Farnell MB, Que FG, Reid-Lombardo KM, Truty MJ, Nagorney DM, et al. Total laparoscopic pancreaticoduodenectomy for pancreatic ductal adenocarcinoma oncologic advantages over open approaches? Ann Surg. 2014;260(4):633-8; discussion 638-40.

11. Kendrick ML, van Hilst J, Boggi $\mathrm{U}$, de Rooij T, Walsh RM, Zeh HJ, et al. Minimally invasive pancreatoduodenectomy. HPB (Oxford). 2017:19(3):215-224.

12. Speicher PJ, Nussbaum DP, White RR, Zani S, Mosca PJ, Blazer 3rd $D G$, et al. Defining the learning curve for team-based laparoscopic pancreaticoduodenectomy. Ann Surg Oncol. 2014; 21(12):4014-9.

13. de Rooij T, Klompmaker S, Hilal MA, Kendrick ML, Busch OR, Besselink MG. Laparoscopic pancreatic surgery for benign and malignant disease. Nat Rev Gastroenterol Hepatol. 2016; 13(4):227-38

14. Boggi U, Amorese G, Vistoli F, Caniglia F, De Lio N, Perrone V, et al. Laparoscopic pancreaticoduodenectomy: a systematic literature review. Surg Endosc. 2015;29(1):9-23. Epub 2014 Aug 15.

15. Buchs NC, Addeo P, Bianco FM, Gangemi A, Ayloo SM, Giulianotti PC. Outcomes of robot-assisted pancreaticoduodenectomy in patients older than 70 years: A comparative study. World J Surg. 2010;34(9): 2109-14.

16. Lee JS, Han JH, Na GH, Choi HJ, Hong TH, You YK, et al. Laparoscopic pancreaticoduodenectomy assisted by mini-laparotomy. Surg Laparosc Endosc Percutan Tech. 2013; 23(3):e98-102.

17. Langan RC, Graham JA, Chin AB, Rubinstein AJ, Oza K, Nusbaum JA, et al. Laparoscopic-assisted versus open pancreaticoduodenectomy: Early favorable physical quality-of-life measures. Surgery. 2014;156(2): 379-84.
18. Palanivelu C, Rajan PS, Rangarajan M, Vaithiswaran V, Senthilnathan P, Parthasarathi $R$, et al. Evolution in techniques of laparoscopic pancreaticoduodenectomy: A decade long experience from a tertiary center. J Hepatobiliary Pancreat Surg. 2009;16(6): 731-40.

19. Dokmak S, Ftériche FS, Aussilhou B, Bensafta Y, Lévy P, Ruszniewski $P$, et al. Laparoscopic pancreaticoduodenectomy should not be routine for resection of periampullary tumors. J Am Coll Surg. 2015;220(5):831-8.

20. Delitto D, Luckhurst CM, Black BS, Beck JL, George Jr 3 TJ, Sarosi GA, et al. Oncologic and perioperative outcomes following selective application of laparoscopic pancreaticoduodenectomy for periampullary malignancies. J Gastrointest Surg. 2016;20(7):1343-9.

21. Zureikat AH, Breaux JA, Steel JL, Hughes SJ. Can laparoscopic pancreaticoduodenectomy be safely implemented? J Gastrointest Surg. 2011:15(7):1151-7.

22. Kendrick ML, Cusati D. Total laparoscopic pancreaticoduodenectomy feasibility and outcome in an early experience. Arch Surg. 2010; 145(1):19-23.

23. Bannone E, Andrianello S, Marchegiani G, Masini G, Malleo G, Bassi C, et al. Postoperative acute pancreatitis following pancreaticoduodenectomy a determinant of fistula potentially driven by the intraoperative fluid management. Ann Surg. 2018;268(5):815-822.

24. Inoue $Y$, Saiura $A$, Yoshioka $R$, Ono $Y$, Takahashi M, Arita J, et al. Pancreatoduodenectomy with systematic mesopancreas dissection using a supracolic anterior artery-first approach. Ann Surg. 2015; 262(6):1092-101.

25. DeSouza A, Domajnko B, Park J, Marecik S, Prasad L, Abcarian H. Incisional hernia, midline versus low transverse incision: What is the ideal incision for specimen extraction and hand-assisted laparoscopy? Surg Endosc. 2011;25(4):1031-6. Epub 2010 Aug 25.

26. Giulianotti PC, Sbrana F, Bianco FM, Elli EF, Shah G, Addeo P, et al. Robot-assisted laparoscopic pancreatic surgery: Single-surgeon experience. Surg Endosc. 2010;24(7):1646-57.

27. Lai ECH, Yang GPC, Tang CN. Robot-assisted laparoscopic pancreaticoduodenectomy versus open pancreaticoduodenectomy - A comparative study. Int J Surg. 2012;10(9):475-9.

28. Boggi U, Signori S, De Lio N, Perrone VG, Vistoli F, Belluomini M, et al. Feasibility of robotic pancreaticoduodenectomy. Br J Surg. 2013; 100(7):917-25.

29. Gumbs AA, Gayet B. The laparoscopic duodenopancreatectomy: the posterior approach. Surg Endosc. 2008 Feb;22(2):539-40.

30. Suzuki O, Kondo S, Hirano S, Tanaka E, Kato K, Tsuchikawa T, et al. Laparoscopic pancreaticoduodenectomy combined with minilaparotomy. Surg Today. 2012;42(5):509-13. Epub 2011 Nov 30.

31. Kim SC, Song KB, Jung YS, Kim YH, Park DH, Lee SS, et al. Short-term clinical outcomes for 100 consecutive cases of laparoscopic pyloruspreserving pancreatoduodenectomy: Improvement with surgical experience. Surg Endosc. 2013:27(1):95-103.

32. Keck T, Wellner UF, Bahra M, Klein F, Sick O, Niedergethmann M, et al. Pancreatogastrostomy versus pancreatojejunostomy for reconstruction after PANCreatoduodenectomy (RECOPANC, DRKS 00000767): Perioperative and long-term results of a multicenter randomized controlled trial. Ann Surg. 2016;263(3):440-9.

33. Karaman K, Bal A, Aziret M, Ercan M, Bostanci EB, Akoglu M. Which suture material is optimal for pancreaticojejunostomy Anastomosis? An In Vitro Study. J Invest Surg. 2017;30(4):277-284.

34. Poon RTP, Fan ST, Lo CM, Ng KK, Yuen WK, Yeung C, Wong $J$ et al. EXternal drainage of pancreatic duct with a stent to reduce leakage rate of pancreaticojejunostomy after pancreaticoduodenectomy: A prospective randomized trial. Ann Surg. 2007;246(3):425-33; discussion 433-5.

35. Winter JM, Cameron JL, Campbell KA, Chang DC, Riall TS, Schulick RD. Does Pancreatic Duct Stenting Decrease the Rate of Pancreatic Fistula Following Pancreaticoduodenectomy? Results of a Prospective Randomized Trial. J Gastrointest Surg. 2006;10(9):1280-90; discussion 1290 